\title{
Application of MEPLWF: method performance evaluation of the Light Wood Frame construction system
}

\author{
Aplicação do MEPLWF: método de avaliação de \\ desempenho do sistema de construção Light Wood Frame
}

\author{
Nicolle Christine Sotsek \\ Drielle Sanchez Leitner \\ Marcell Mariano Corrêa Maceno \\ Marcos Augusto Mendes Marques \\ Adriana de Paula Lacerda Santos
}

Abstract

performance of light wood frame buildings in Brazil. The structure of the method used, named MEPLWF, is based on five dimensions, which involve criteria and sub-criteria that analyse technical, social, environmental and economic requirements to evaluate buildings. It allows the examination of the operating results of buildings and the discovery of performance-related problems. The proposed method was applied in a real case study in southern Brazil, during the pre-occupation phase of the building. As a result, the performance identified in the building was $94 \%$, which is a high performance. The application of the method in this case study diagnosed points that should be reviewed by the construction company, such as items related to fire protection and safety, flexibility and adaptability of the building system, environmental plan, energy efficiency and Costs.

Keywords: Light wood frame. Building performance evaluation. Sustainable development goals.

${ }^{1}$ Nicolle Christine Sotsek 'Universidade Federal do Paraná Curitiba - PR - Brasil

${ }^{2}$ Drielle Sanchez Leitner Universidade Federal do Paraná Curitiba - PR - Brasil

${ }^{3}$ Marcell Mariano Corrêa Maceno 3Universidade Federal do Paraná Curitiba - PR - Brasil

${ }^{4}$ Marcos Augusto Mendes Marques ${ }^{4}$ Universidade Federal do Paraná Curitiba - PR - Brasil

${ }^{5}$ Adriana de Paula Lacerda Santos ${ }^{5}$ Universidade Federal do Paraná Curitiba - PR - Brasil

Recebido em 12/05/20 Aceito em 23/09/20

\section{Resumo}

Dos 17 Objetivos de Desenvolvimento Sustentável (ODS) abordados nesta agenda, o objetivo 11 está relacionado à busca por cidades e comunidades mais sustentáveis. Para contribuir com este objetivo, este estudo apresenta uma aplicação de método para avaliar o desempenho de construções em light wood frame no Brasil. O método utilizado, denominado MEPLWF baseia sua estrutura em cinco dimensões, que envolvem critérios e subcritérios que analisam requisitos técnicos, sociais, ambientais e econômicos de uma edificação. Permite examinar os resultados operacionais do edifício e descobrir problemas relacionados ao desempenho. O método proposto foi aplicado em um estudo de caso real no sul do Brasil, na fase pré-ocupação da edificação. Como resultado, o desempenho identificado no edifício foi de $94 \%$, o que representa um alto desempenho. A aplicação do método neste estudo de caso diagnosticou pontos que devem ser revistos pela empresa de construção, como itens relacionados à proteção e segurança contra incêndio, flexibilidade e adaptabilidade do sistema predial, plano ambiental, eficiência energética e custos.

Palavras-chave: Light wood frame. Avaliação de desempenho de contrução. Metas de desenvolvimento sustentável.

SOTSEK, N. C.; LEITNER, D. S.; MACENO, M. M. C.; MARQUES, M. A. M.; SANTOS, A. de P. L. Application of MEPLWF: 197 method performance evaluation of the Light Wood Frame construction system. Ambiente Construído, Porto Alegre, v. 21, n. 3, p. 177-211, jul./set. 2021.

ISSN 1678-8621 Associação Nacional de Tecnologia do Ambiente Construído. http://dx.doi.org/10.1590/s1678-86212021000300546 


\section{Introduction}

Due to the expansion of the construction industry worldwide, a high demand for materials is emerging (JADID; BADRAH, 2012). This demand does not refer only to the search for new supplies, but also to the search for more sustainable materials and buildings, concerned with the environmental, social and economic aspects of a building. Thus, the search for new materials, previously guided by requirements such as cost and time, now also takes into account environmental and social factors (LIU; QIAN, 2019).

This can be explained since, according to Karlsson, Rootzen and Johnsson (2020), the construction sector accounts for approximately one quarter of global $\mathrm{CO}_{2}$ emissions. Ma et al. (2017) further emphasize that the construction segment is responsible for generating high rates of solid waste and for causing various types of environmental pollution. For these reasons, many countries have been looking for more efficient constructive alternatives in order to meet their sustainability protocols (MAHAPATRA; GUSTAVSSON; HEMSTROM, 2012).

Finland, for example, has submitted plans for all construction in the country starting in 2017 to use more efficient resources and inputs to meet the energy efficiency target, set in 2010. In the UK, a "code for sustainable homes" has been mandatory for all new homes since 2008. The UN itself established in 2015 Agenda 2030, which has 17 Sustainable Development Goals (SDG) to transform the world. Among them, SDG 11 is related to more sustainable cities and communities and SDG 9 is related to the construction of reliable, sustainable and resilient quality infrastructures (NATION..., 2020). These data show that the concern for the search for more efficient and sustainable building systems is eminent (MAHAPATRA; GUSTAVSSON; HEMSTROM, 2012).

In this way, encouraging the use of wood in buildings would help to achieve not only local but worldwide SDG (WANG; TOPPINEN; JUSLIN, 2014). For Antikainen et al. (2017) wood construction is one of the most promising ways to seek a more sustainable bio economy.

Based on this assumption, light wood frame (LWF) is a constructive system that presents environmental, social and economic advantages due to its characteristics of material rationalization, operational flexibility, productive agility, competitive costs and, also, efficient cleaning levels and assembly time (SOTSEK; SANTOS, 2018).

The system uses as main input pieces of solid sawn wood and coating sheets, including wood panels. For Gold and Rubik (2009) wood is a renewable resource that can contribute to the establishment of more sustainable patterns of both consumption and production.

Most wood has easy workability, excellent acoustics and thermal performance (absorbing 40 times less heat than brick masonry), as well as high strength/weight ratio (MOLINA; CALIL JUNIOR, 2010), which makes this material a promising input for the construction industry. In addition, wood is a renewable and abundant resource mainly in tropical countries, due to the weather.

Another consideration of this input refers to its use in the construction, since the material allows fixing carbon, minimizing the $\mathrm{CO}_{2}$ release in the atmosphere.

However, this system is still considered innovative and is little applied in Latin American countries, which have as a construction culture the use of masonry blocks (SOTSEK; SANTOS, 2018).

Therefore, this study aimed to apply a method for LWF performance analysis in Brazil, in order to present its sustainability and efficiency advantages as a constructive system to expand and diffuse the system mainly in tropical countries. Sotsek et al. (2020) developed this method, consisted by 5 dimensions, which cover criteria and sub-criteria that assess technical, social, environmental and economic requirements of a building.

This method was established considering the eminent concern of constructing buildings that meet the global sustainability protocol and the assurance of human well-being. It can be applied during the stages of the building lifecycle, such as pre-occupation, occupation and post-occupation, and then can be compared to measure the performance of the building throughout its lifecycle. It is named MEPLWF (method for evaluating the performance of light wood frame). Therefore, the objective of this research is to present the application of the MEPLWF method in an LWF building in Brazil.

\section{Material and methods}

This topic presents the MEPLWF method, its conduction for application in a building, and the case study investigated.

198 Sotsek, N. C.; Leitner, D. S.; Maceno, M. M. C.; Marques, M. A. M.; Santos, A. de P. L. 


\section{MEPLWF method}

The method adopted in Sotsek et al. (2020) was established using the identification and selection of building evaluation criteria and sub-criteria that involve technical, environmental, social and economic aspects. It was composed of 5 dimensions and 19 criteria.

Through the weights assigned to each criteria, it is possible to identify or execute the performance measured in the studied edition. For a detailed description of the weight of each sub-criteria, see Sotsek et al. (2020). A summary version of this score can be seen in Table 1, which shows the highest score levels, that is, those with the most relevance during the performance evaluation of an LWF building.

Among the 5 established dimensions, dimension 4 obtained the highest score, with 68 points. This dimension refers to the criteria related to structural durability, maintenance and sealing. These criteria indicate the need to preserve wood, the main component in light wood frame buildings.

For this, its users must do the maintenance of the building during its useful life correctly and, especially, the wood should be properly sealed to avoid direct contact with water and xylophages insects that can degrade the material. The preservation of the material enables the building to have a positive impact on its economic performance since, with the correct preventive and continuous maintenance of the wood, its structure may remain for years.

Thus, there will also be a positive impact on the environmental performance of the building as this preservation ensures greater durability of the building, consequently reducing the extraction of natural resources aiming at replacing.

The second highest score was achieved by dimension 2, with 42 points, which measures the comfort of the building encompassing the concern with the environmental and social aspects of the building, including concern for the residents' well-being. This result is consistent with the literature.

Table 1 - The MEPLWF method

\begin{tabular}{|c|c|c|c|c|c|}
\hline \multirow{2}{*}{$\begin{array}{l}\text { Criteria for performance analysis } \\
\text { of buildings in Light Wood Frame } \\
\text { (LWF) }\end{array}$} & \multirow[b]{2}{*}{ Points } & \multirow{2}{*}{$\begin{array}{c}\text { Percentage } \\
(\%)\end{array}$} & \multicolumn{3}{|c|}{ Triple bottom line } \\
\hline & & & Environmental & Social & Economic \\
\hline 1. Dimension 1 & 20 & 12 & & & \\
\hline 1.1 Protection and Security & 9 & 5 & & $\mathrm{X}$ & \\
\hline 1.2 Electrical installations & 3 & 2 & & $\mathrm{X}$ & \\
\hline 1.3 Hydraulic facilities & 3 & 2 & & $\mathrm{X}$ & \\
\hline 1.4 Telecommunication facilities & 1 & 1 & & $\mathrm{X}$ & \\
\hline 1.5 Organization of the environment & 4 & 2 & & $\mathrm{X}$ & \\
\hline 2. Dimension 2 & 42 & 25 & & & \\
\hline 2.1 Thermal comfort & 30 & 17 & $\mathrm{X}$ & & \\
\hline 2.2 Acoustic comfort & 6 & 3 & & & \\
\hline 2.3 Visual comfort & 1 & 1 & $\mathrm{X}$ & & \\
\hline 2.4 Internal air quality & 5 & 3 & $\mathrm{X}$ & & \\
\hline 3. Dimension 3 & 11 & 6 & & & \\
\hline 3.1 Building documentation & 6 & 3 & & $\mathrm{X}$ & \\
\hline 3.2 Training of residents & 1 & 1 & & $\mathrm{X}$ & \\
\hline 3.3 Facility management by residents & 3 & 2 & & $\mathrm{X}$ & \\
\hline 4. Dimension 4 & 68 & 39 & & & \\
\hline 4.1 Structural Durability & 11 & 6 & $\mathrm{X}$ & & $\mathrm{X}$ \\
\hline 4.2 Maintenance & 3 & 2 & $\mathrm{X}$ & & $\mathrm{X}$ \\
\hline 4.3 Sealing & 53 & 31 & $\mathrm{X}$ & & $\mathrm{X}$ \\
\hline 5. Dimension 5 & 31 & 18 & & & \\
\hline 5.1 Satisfaction of residents & 17 & 10 & & $\mathrm{X}$ & \\
\hline 5.2 Energy Efficiency & 3 & 2 & $\mathrm{X}$ & & \\
\hline 5.3 Costs & 4 & 2 & $\mathrm{X}$ & & $\mathrm{X}$ \\
\hline 5.4 Physical appearance & 7 & 4 & & $\mathrm{X}$ & \\
\hline TOTAL & 173 & 100 & & & \\
\hline
\end{tabular}

Source: adapted from Sotsek et al. (2020). 
Several studies indicate the analysis of thermal, acoustic, visual and air quality comfort of buildings as the main factors to be studied in research related to building performance evaluation (BPE) (LAI; MAN, 2017; NAZEER; SILVA, 2016; KHALIL; KAMARUZZAMAN; BAHARUM, 2016; IBEM et al., 2013).

In this context, given the total score of 173 points, to $100 \%$, a score that could be used as a mechanism for evaluating these buildings during the pre-occupation, occupation and post-occupation phases was established. That is, through the evaluated sub-criteria, the buildings may present a performance value for each of the 5 established dimensions.

This score was prepared considering the percentage of performance served by the building, as the work of Hong (2007) and Green Globes certification stipulate. A building that meets $50 \%$ of the criteria will be considered a building with minimum performance; $51-75 \%$ average performance; and, above $76 \%$ high performance.

\section{Conducting the application of the MEPLWF method}

In order to apply the MEPLWF method established by Sostek et al. (2020), the steps were followed to carry out this activity, namely:

(a) definition of the study scope;

(b) information collection;

(c) performance verification; and

(d) analysis results.

Figure 1 shows the flowchart of the method steps.

\section{Definition of the study scope}

In step 1, two activities must be performed. The definition of the analysis unit and the research strategy. The analysis unit comprises to select the LWF building that will be studied.

The research strategy comprises to define what the objective of the analysis is:

(e) if it is to verify the current performance of the building, presenting an indicative of the performance;

(f) if it is to improve the performance of the building, through an investigation, reporting appropriate solutions to the identified problems; or

(g) if it is to seek improvements for future projects, generating a detailed diagnosis of the building to generate a report with lessons learned.

Figure 1 - Conducting the application the of MEPLWF

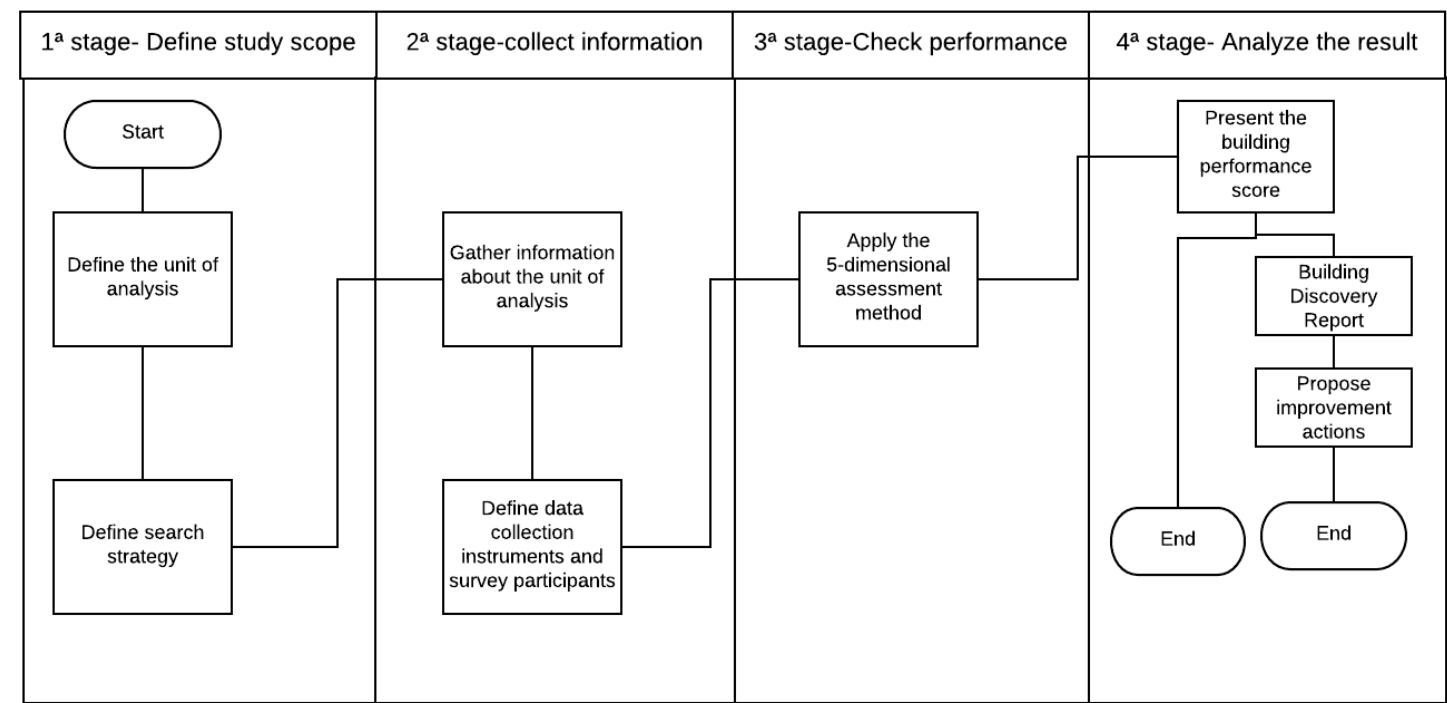

Nota: ${ }^{*} 1^{\text {st }}$ stage; $2^{\text {nd }}$ stage; $3^{\text {rd }}$ stage; and $4^{\text {th }}$ stage.

200 Sotsek, N. C.; Leitner, D. S.; Maceno, M. M. C.; Marques, M. A. M.; Santos, A. de P. L. 


\section{Collecting information}

In step 2, two activities are performed. The first activity is to gather information about the building, i.e. to check which life cycle phase the building is in, if pre-occupation, occupation, or post-occupation. The second is to seek the building documentation, such as: work, user manual, technical documents, descriptive memorial, project plans, certifications of the building used components, among others. This information is required to know the building.

The second activity aims to define the collection instruments and the research participants. Depending the life cycle phase the building is in, it is possible to collect information from users/residents and/or the technical team; to perform an on-site inspection of the user manual and documents submitted; and to perform measurements using appropriate instruments to verify the performance and/or also to use simulation software.

This activity should be defined according to researchers' available resources and according to the characteristics of the criteria to be analyzed. Qualitative criteria are usually measured through interviews, questionnaires, surveys, on-site observations, while instruments or simulators must measure quantitative criteria.

\section{Verifying performance}

In step 3, the proposed method with the 5 dimensions is applied, i.e. the criteria are verified one by one according to established information gathering. The checking is to show if the criteria attended or not the requirement requested.

The researcher performs this activity in the form of a checklist, e.g. if the criteria is quantitative and should be measured, the researcher can use an instrument to measure it and the standard guide to verify if it was attended or not.

\section{Analyzing results}

In the last step, depending on the strategy, two scenarios may exist. If the strategy is "to verify the current performance: indicative" then only the score will be presented in this final step. If the strategy is "to improve the performance: investigative" or "to seek improvements for future projects: diagnosis" then two activities are performed.

The first is to present the identified score for the building, according to the checklist made, and the second is to show flaws found during the analysis, i.e. to present a finding report that indicates the criteria that were not attended, and that should be reviewed and discussed.

\section{Application of the MEPLWF method in a Brazilian building}

This section presents an application of the method in a building in southern Brazil. The case study is a LWF building that was built in 2019 and consists of 4 floors. Each floor has 4 apartments with footage ranging from $39.99 \mathrm{~m}$ to $41.58 \mathrm{~m}$. The floor plan is the same for all apartments, consisting of living room, kitchen with laundry, two bedrooms and bathroom (Figure 2). For this study, an apartment on the first floor was evaluated.

The building system has floors and walls structured in accordance with the documents governing the LWF in Brazil: DATec $\mathrm{n}^{\circ}$ 020C (TECVERDE et al., 2016) and SINAT 005 (BRASIL, 2017). Frames of treated sawn wood; OSB boards, rock wool as an insulator, gypsum plasterboard and outer wall covering by cement board.

The objective of this evaluation is to investigate the building performance during the pre-occupation phase. Thus, the instruments used for analysis of criteria can be seen in Table 2.

Data collection was conducted in September 2019 during the spring season. The day in question was cloudy, and the weather conditions were suitable for the measurement of natural light and noise level, sub-criteria that had such information specified in the Brazilian performance standard. The pre-occupancy assessment started at 8 am with arrival at the project site and assembly of the workstations. 
Figure 2 - Floor plan of the analyzed apartment

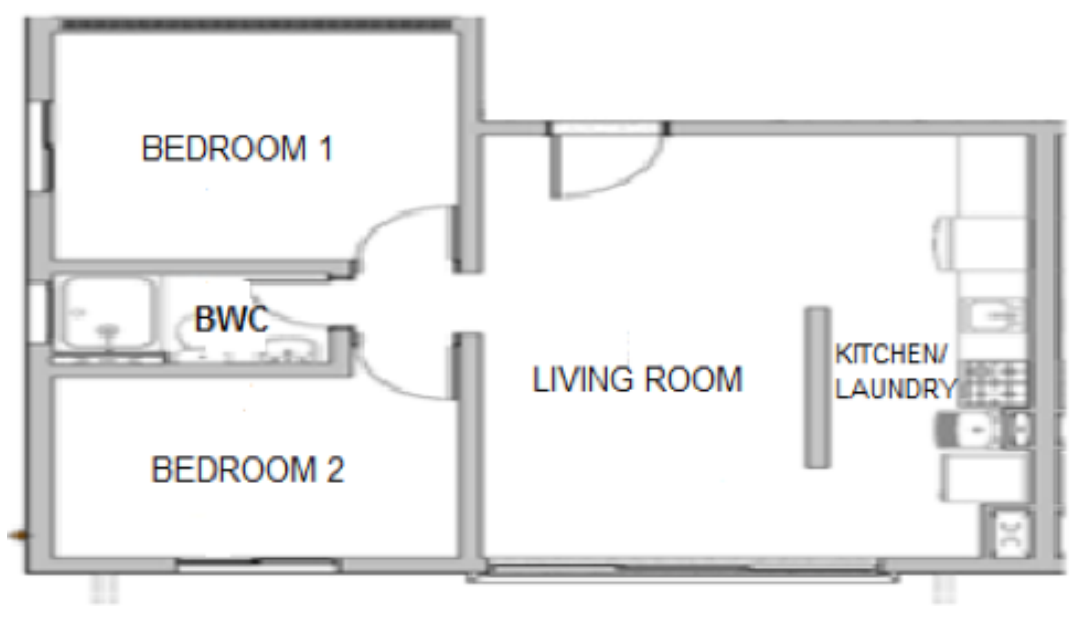

Table 2 - Instruments used to measure LWF building performance

\begin{tabular}{|c|c|c|c|c|}
\hline \multirow[b]{2}{*}{ 离 } & \multirow[b]{2}{*}{ Criteria } & \multicolumn{3}{|c|}{ Used tools } \\
\hline & & $\begin{array}{c}\text { Inspect project } \\
\text { and site work/ } \\
\text { user manual }\end{array}$ & Quiz & Measure used equipment \\
\hline \multirow{5}{*}{1} & Protection and Security & $\mathrm{X}$ & $\mathrm{X}$ & \\
\hline & Electrical installations & $\mathrm{X}$ & & \\
\hline & Hydraulic facilities & $\mathrm{X}$ & & \\
\hline & Telecommunications facilities & & $\mathrm{X}$ & \\
\hline & Organization of the environment & $\mathrm{X}$ & & \\
\hline \multirow{4}{*}{2} & Thermal comfort & & & $\begin{array}{l}\text { Hygrometer and temperature } \\
\text { datalogger term }\end{array}$ \\
\hline & Acoustic comfort & & & $\begin{array}{l}\text { Sound level meter (decibel } \\
\text { meter) }\end{array}$ \\
\hline & Visual comfort & & & Portable lux meter \\
\hline & Internal air quality & & & $\begin{array}{l}\text { Anemometer and thermo } \\
\text { hygrometer }\end{array}$ \\
\hline \multirow{3}{*}{3} & Building documentation & X & & \\
\hline & Training of residents & & $\mathrm{X}$ & \\
\hline & Facility management by residents & & $\mathrm{X}$ & \\
\hline \multirow{3}{*}{4} & Structural Durability & & $\mathrm{X}$ & \\
\hline & Maintenance & & $\mathrm{X}$ & \\
\hline & Sealing & $\mathrm{X}$ & & \\
\hline \multirow{4}{*}{5} & Satisfaction of residents & & $\mathrm{X}$ & \\
\hline & Energy Efficiency & $\mathrm{X}$ & & \\
\hline & Costs & $\mathrm{X}$ & & \\
\hline & Physical appearance & $\mathrm{X}$ & $\mathrm{X}$ & \\
\hline
\end{tabular}

The measurements followed the three defined collection cycles: morning, afternoon and early evening. The data collected were compared with minimum performance requirements presented in the Brazilian performance standard.

These instruments were chosen based on what the literature recommends to assess these criteria. The questionaire was conducted with two representatives of the building: the master builder and the project manager.

The field inspection and project analysis were done on-site with the supervision of the master builder before the building was handed over to residents. Data collection was performed on one day of the week. 
The research used as a reference to evaluate the criteria the performance standard that governs buildings in Brazil: NBR 15575-1 (ABNT, 2013a). This standard refers to other specific standards that will also be considered in this research. The result of the analysis of each dimension is presented hereafter.

\section{Results and discussions}

This topic aims to present the results found during the application of the MEPLWF method.

\section{Dimension 1 application analysis result}

Dimension 1 was analyzed using two instruments: inspection and questionaire. The requirements inspected and questioned were based on what the performance standard NBR 15575-1 (ABNT, 2013a) establishes for this type of building, that is, each item established in the standard was checked during the inspection or through the questionaire.

As a result, dimension 1 presented a score of 17 out of 20. As Table 3 details, some sub-criteria were not met. The sub-criteria "fire safety" partially complied with the standard. In the case of the item "fire doors", such features were not installed in the building. The technical team reviewed this item promptly.

The "flexibility and adaptability" sub-criteria also did not meet the performance standard. According to NBR 15575-1 (ABNT, 2013a) a flexible and adaptable system, such as LWF, must provide information and technical details about interfaces between this innovative building system and traditional / regional systems. In addition, it shall also provide information on both innovative and conventional technical and material infrastructure compatible with the innovative building system.

In the studied case, the user manual does not present the LWF's relationship with other systems. Therefore, it is recommended that this information be incorporated into the user manual. It is known that LWF is a modular and flexible system, but as it is innovative, it must be made accessible to users, showing its correlations with other building systems, as an example.

Table 3 - Dimension 1 evaluation

\begin{tabular}{|c|c|c|c|c|}
\hline \multirow{2}{*}{$\begin{array}{l}\text { Dimension } 1 \\
1.1 \text { Protection and Security }\end{array}$} & \multirow{2}{*}{$\begin{array}{c}\text { Theoretical } \\
\text { score } \\
\end{array}$} & \multicolumn{2}{|c|}{ Practice } & \multirow{2}{*}{$\begin{array}{c}\text { Identified } \\
\text { score } \\
\end{array}$} \\
\hline & & Yes & No & \\
\hline 1.1.1 Fire Safety & 2 & & $\mathrm{X}$ & 0 \\
\hline $\begin{array}{l}\text { 1.1.2 Protection against microorganisms, insects and dangerous } \\
\text { animals }\end{array}$ & 2 & $\mathrm{X}$ & & 2 \\
\hline 1.1.3 Safety regarding structural strength (walls) & 5 & $\mathrm{X}$ & & 5 \\
\hline \multicolumn{5}{|l|}{ 1.2 Electrical installations } \\
\hline $\begin{array}{l}\text { 1.2.1 Easy access to electrical components (sockets and } \\
\text { connectors) }\end{array}$ & 2 & $\mathrm{X}$ & & 2 \\
\hline $\begin{array}{l}\text { 1.2.2 Cleaning and safety of electrical installation components } \\
\text { (sockets and connectors) }\end{array}$ & 1 & $\mathrm{X}$ & & 1 \\
\hline \multicolumn{5}{|l|}{ 1.3 Hydraulic facilities } \\
\hline 1.3.1 Easy access to hydraulic mechanisms & 2 & $\mathrm{X}$ & & 2 \\
\hline $\begin{array}{l}\text { 1.3.2 Cleanliness and safety of indoor and outdoor sanitary } \\
\text { facilities }\end{array}$ & 1 & $X$ & & 1 \\
\hline \multicolumn{5}{|l|}{ 1.4 Telecommunications Facilities } \\
\hline $\begin{array}{l}\text { 1.4.1 Easy access to telecommunications mechanisms } \\
\text { (telephone, internet, among others) }\end{array}$ & 1 & $\mathrm{X}$ & & 1 \\
\hline \multicolumn{5}{|l|}{ 1.5 Organization of the environment } \\
\hline $\begin{array}{l}\text { 1.5.1 Preventive and continuous maintenance plan in all } \\
\text { installations (electrical, hydraulic, thermal if any, among others) }\end{array}$ & 3 & $\mathrm{X}$ & & 3 \\
\hline 1.5.2 Flexibility and adaptability & 1 & & $\mathrm{X}$ & 0 \\
\hline TOTAL & 20 & & & 17 \\
\hline
\end{tabular}




\section{Dimension 2 application analysis result}

Dimension 2 was analyzed using measurement instruments. All criteria met the minimum performance values. For the thermal comfort criteria, three rooms of the apartment met the standard requirements, as shown in Table 4.

The internal temperature was collected for 3 cycles using a thermo-hygrometer, as in the case of external temperature a datalogger was used. To meet this criteria, the internal temperature must be lower than outdoor in summer and at least $3{ }^{\circ} \mathrm{C}$ higher than outdoor in winter NBR 15575-1 (ABNT, 2013a).

It is noteworthy that the research was conducted in spring, but, as there is no reference in the standard for this period, the comparison was made for the winter and summer seasons, which are the climatic extremes.

The thermal variation of the building was analyzed during the three collection cycles comparing the internal and external temperatures. Figures 3, 4 and 5 show that internal temperatures remain at the center of the graphs, where the average temperatures of the day are.

In other words, when comparing the external variation line of the three cycles and the internal variation line, it is noted that the building is able to maintain the internal temperature more constant and milder than the external conditions.

Regarding acoustic comfort, data collection was performed with a portable sound level meter. In order to assess the difference between internal and external noises, measurements were made with both opened and closed openings (doors and windows).

Four measurements per cycle were made in each room, two with closed doors and openings and two with opened doors and windows.

Table 4 - Bioclimatic chart NBR 15575-1 (ABNT, 2013a)

\begin{tabular}{|c|c|c|c|c|c|c|}
\hline Rooms & $\begin{array}{c}\text { Maximum } \\
\text { internal } \\
\text { temperature } \\
\left({ }^{0} \mathrm{C}\right)\end{array}$ & $\begin{array}{c}\text { Maximum } \\
\text { external } \\
\text { temperature } \\
\left({ }^{0} \mathrm{C}\right)\end{array}$ & Summer & $\begin{array}{c}\text { Maximum } \\
\text { internal } \\
\text { temperature } \\
\left({ }^{\circ} \mathrm{C}\right)\end{array}$ & $\begin{array}{c}\text { Maximum } \\
\text { external } \\
\text { temperature } \\
\left({ }^{0} \mathrm{C}\right)\end{array}$ & Winter \\
\hline Bedroom 1 & 25.5 & \multirow{3}{*}{26.4} & Yes & 22.5 & \multirow{3}{*}{19.1} & Yes \\
\hline Bedroom 2 & 25.3 & & Yes & 22.8 & & Yes \\
\hline Living room & 26,5 & & Yes & 22,1 & & Yes \\
\hline
\end{tabular}

Source: ABNT (2013a).

Figure 3 - Internal and External Temperature Variation in Bedroom 1

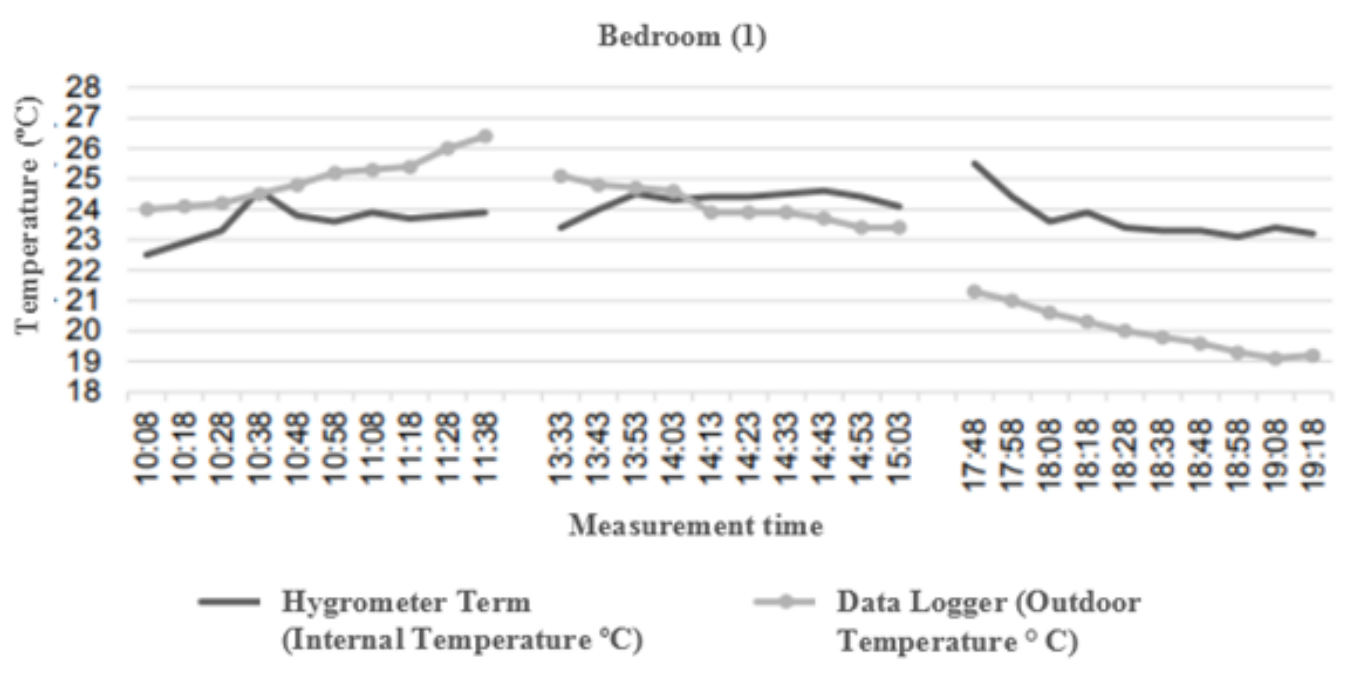

204 Sotsek, N. C.; Leitner, D. S.; Maceno, M. M. C.; Marques, M. A. M.; Santos, A. de P. L. 
Figure 4 - Internal and External Temperature Variation in Bedroom 2

Bedroom (2)

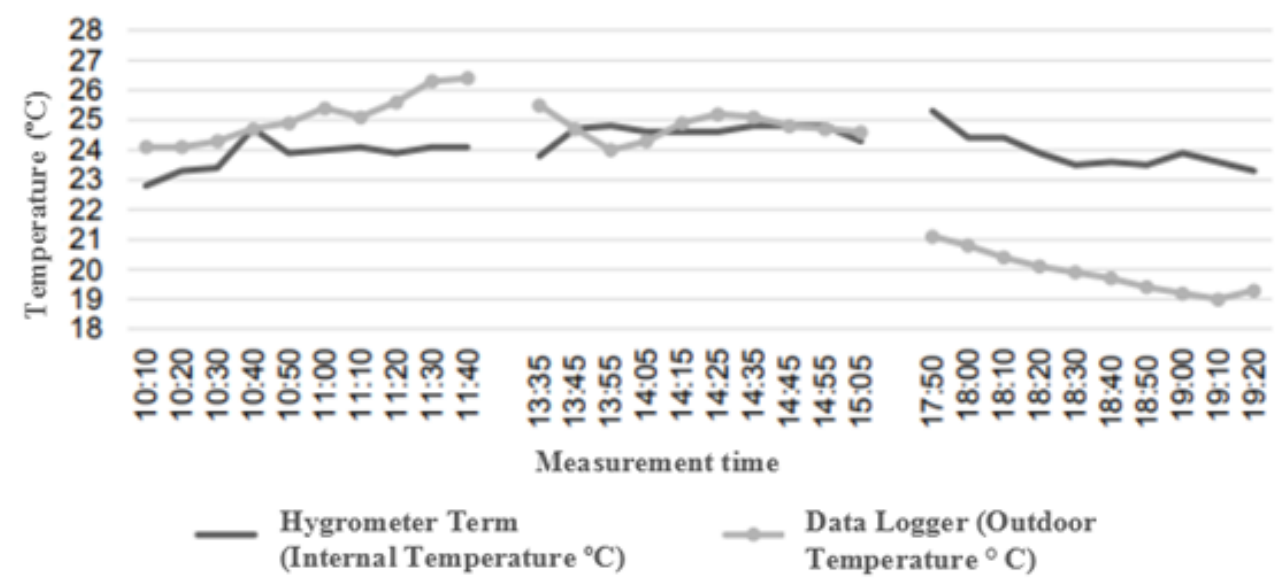

Figure 5 - Internal and External Temperature Variation in the living room

Living room
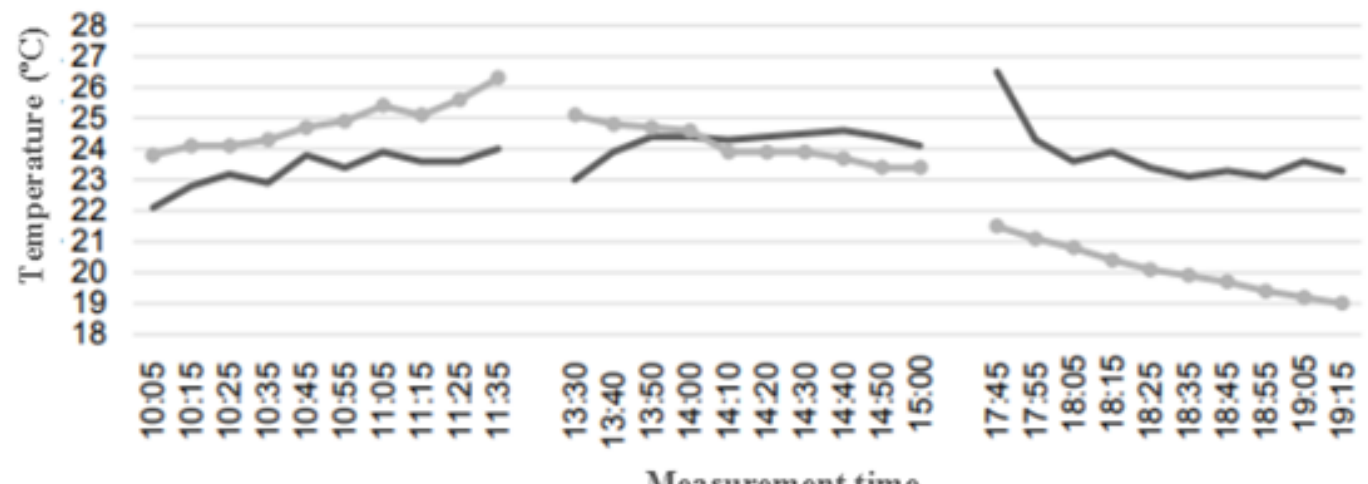

Measurement time

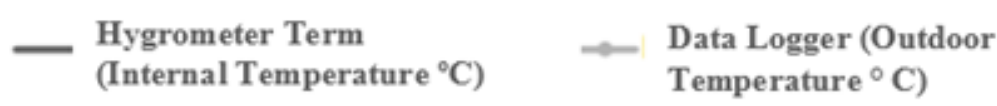

After all measurements were made, the equivalent sound pressure level in each room, called LAeq, with A being any room, was calculated, following the equation presented in ISO 10052 (INTERNATIONAL..., 2004), NBR 10151 (ABNT, 2003) and NBR 10152 (ABNT, 2007) (Equation 1).

LAeq $=10 x \log 10\left[\frac{1}{n} x\left(10 \frac{\text { Laeq, } 30 s, p 1}{10}+\cdots+10 \frac{\text { Laeq, } 30 s, p n}{10}\right)\right] d B$ Eq. 1

The letter " $n$ " represents the number of measurement points distributed in the environment. In this case, 30 measurements were made in the same place of each room, considering the size of the room.

The LAeq is the level obtained from the value sound pressure quadratic mean.

The "LAeq, 30s, pn" represents the sound pressure level, in "dB" read in rapid response every 30s, during the measurement time of noise, and the " $\mathrm{dB}$ " means decibels.

According to NBR 10152 (ABNT, 2017, p. 17), “[...] when measurements are made by the simplified method, the assessment is performed by comparing the sound pressure levels, equivalent LAeq and maximum LASmax, representative of the environment [...]" with the values presented in norm of RLAeq and RLASmax respectively, as presented in Table 5. It is emphasized that LASmax is the maximum value measured in that cycle and environment. 
Table 5 - Analysis of acoustic comfort of the building

\begin{tabular}{|c|c|c|c|c|}
\hline \multirow{2}{*}{$\begin{array}{l}\text { Identified Values (Closed doors and } \\
\text { windows) }\end{array}$} & \multicolumn{4}{|c|}{ LAeq $(\mathrm{dB})$} \\
\hline & Measurement & Cycle 1 & Cycle 2 & Cycle 3 \\
\hline \multirow{2}{*}{ Bedroom 1} & 1 & 27.4 & 29 & 26.3 \\
\hline & 2 & 23.4 & 30.6 & 293 \\
\hline \multirow{2}{*}{ Bedroom 2} & 1 & 28.2 & 30.4 & 23.9 \\
\hline & 2 & 27.6 & 32.7 & 20.8 \\
\hline \multirow{2}{*}{ Living room } & 1 & 25.5 & 28.9 & 30.7 \\
\hline & 2 & 30 & 31.7 & 26.6 \\
\hline Identified Values (Open doors and windows) & Measurement & Cycle 1 & Cycle 2 & Cycle 3 \\
\hline \multirow{2}{*}{ Bedroom 1} & 1 & 41.9 & 43.2 & 43 \\
\hline & 2 & 42.8 & 43.7 & 43.6 \\
\hline \multirow{2}{*}{ Bedroom 2} & 1 & 43.8 & 45.7 & 41.4 \\
\hline & 2 & 44.6 & 46.4 & 41.9 \\
\hline \multirow{2}{*}{ Living room } & 1 & 48.7 & 47.8 & 46 \\
\hline & 2 & 46.3 & 47.5 & 44.6 \\
\hline Reference NBR Standard Values (10152) & \multicolumn{4}{|c|}{$\mathbf{R} L A e q(\mathbf{d B})$} \\
\hline Bedroom & \multicolumn{4}{|c|}{35} \\
\hline Living room & \multicolumn{4}{|c|}{40} \\
\hline Reference NBR Standard Values (10152) & \multicolumn{4}{|c|}{$R L A S \max (\mathbf{d B})$} \\
\hline Dormitory & \multicolumn{4}{|c|}{40} \\
\hline Living room & \multicolumn{4}{|c|}{45} \\
\hline
\end{tabular}

As a result, as for $R L A e q$, both bedrooms and the living room met the norm when evaluating measurements with (windows and doors) openings and did not meet it when they were opened. The same situation was repeated for RLASmax, the bedrooms and living room met the maximum sound pressure levels with the (windows and doors) closed and did not meet the (windows and doors) opened.

Although the results with the open windows did not meet the values proposed in the standard, comparing these values with the values measured outdoors (without the acoustic protection of the building), it is clear that, even with the open windows, the building absorbed considerably the external noises, especially in relation to the dormitories, which should be the quietest environments.

In addition, the resident, by simply closing his windows, is able to adjust the acoustic performance of the building to comply with the values imposed by standard.

With regard to natural lighting, the results obtained showed that all rooms analyzed, these being those suggested by the standard (living room, kitchen/pantry, service area and bedrooms), met the standard in all readings made. It is noteworthy that the standard does not indicate a minimum number of readings to be taken in each room.

For this purpose, it was chosen to perform 10 readings over the 2 measurement cycles (morning and afternoon).

To calculate the FLD (daylight factor), which is the standard item for on-site daylight measurements, one should also measure the natural lighting in an external point of the building in the shade. After such information has been collected, Equation 2, presented in NBR 15575-1 (ABNT, 2013a), is used:

$F L D=100 X \frac{E i}{E e}$

Ei is luminance within dependence; and

Ee is external luminance in the shade.

To meet the minimum level of natural illumination performance by spot measurement, the FLD must be greater than or equal to $0.50 \%$ in the defined rooms. Bedrooms 1 and 2 were the rooms with the best results. In addition, one of the readings in Bedroom 1, in the second measurement cycle, showed that the lighting on site was the same as that on the outside, resulting in a $100 \%$ FLD.

Finally, for the "air quality" criteria, natural ventilation and air humidity were measured. Natural ventilation was assessed by design analysis, as provided in NBR 15575-4 (ABNT, 2013b) in the requirement for 
ventilation openings. In the case of bioclimatic zone 1 (Curitiba), the norm indicates that in extended-stay environments the area of openings should be greater than $7 \%$ of the floor area. As can be seen in Table 6 all rooms met the requirements.

To perform the relative humidity evaluation, the Analysis Bio tool was used. In the tool, the climate file of the city in question was inserted so that its bioclimatic chart could be elaborated.

To arrive at the assessment result, which indicates the comfort zone in which that environment is, temperature and humidity data must be correlated. In this case, the dry bulb temperature was related to the relative humidity, represented by the red curves in Figure 6.

Thus, it is then possible to locate points within the chart, checking in which bioclimatic zone each point is inserted.

As a result, all temperature and relative humidity intersection points are within the bioclimatic comfort zone, which means that in the evaluated rooms, the occupants are in environments that does not need to be cooled or heated.

Regarding the humidity in the building, the data collection was done in two cycles (morning and afternoon) using as instrument a thermo-hygrometer. The variation of relative air humidity did not exceed $7 \%$, maintaining a practically constant value of $6.5 \%$. It is noted that a smaller variation in the relative humidity can positively influence the thermal comfort of the building since it does not require its occupant a very sudden adaptation to the environment.

Table 6 - Natural ventilation in the studied building

\begin{tabular}{l|c|c|c|c|c}
\hline \multicolumn{7}{c|}{ Data in the studied building } \\
\hline Room & $\begin{array}{c}\text { Floor } \\
\text { area }\left(\mathbf{m}^{2}\right)\end{array}$ & $\begin{array}{c}\text { Opening } \\
(\mathbf{c m})\end{array}$ & $\begin{array}{c}\text { Opening } \\
\text { area }\left(\mathbf{m}^{2}\right)\end{array}$ & $\begin{array}{c}\text { Considered } \\
\text { area }\left(\mathbf{m}^{\mathbf{2}}\right)\end{array}$ & $\begin{array}{c}\text { Ratio } \\
(\mathbf{\%})\end{array}$ \\
\hline Bedroom 1 & 9.00 & $120 \times 120$ & 1.44 & 0.72 & 8.00 \\
Bedroom 2 & 7.52 & $120 \times 120$ & 1.44 & 0.72 & 9.57 \\
Living room + Kitchen & 21.88 & $290 \times 160$ & 4.64 & 3.09 & 14.14 \\
\hline
\end{tabular}

Figure 6 - Bioclimatic chart of the studied city

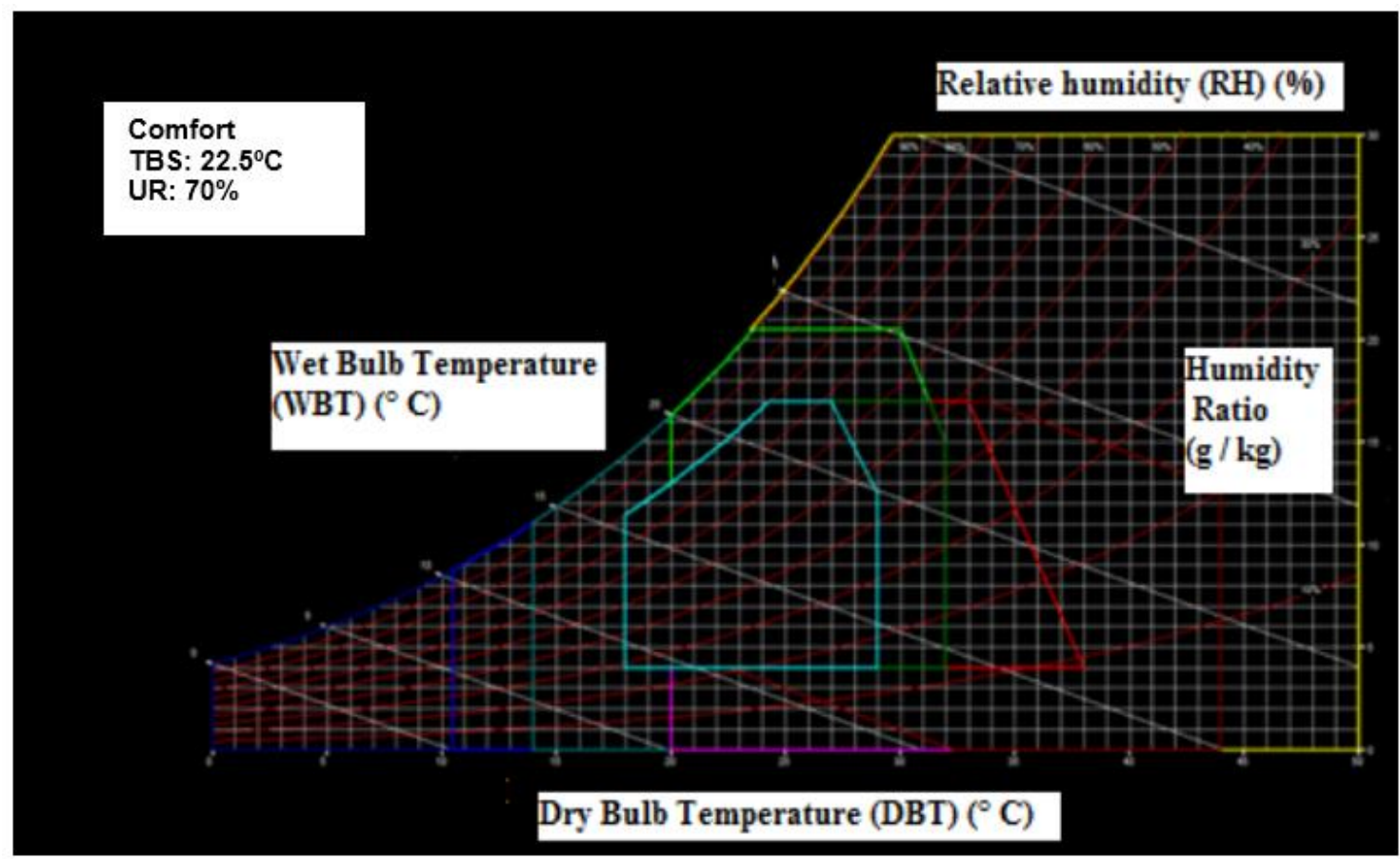

Application of MEPLWF: method performance evaluation of the Light Wood Frame construction system 


\section{Dimension 3 application analysis result}

Dimension 3 was analyzed by questionaire and inspection. As a result, only the sub-criteria "environmental plan" was not fully met. An environmental plan was not identified for this building, that is, guidelines that refer to the use of natural resources in a sustainable way, such as selective waste collection, rainwater harvesting and reuse, use of renewable energy, among others.

The only guideline identified refers to proper disposal and maintenance with respect to sanitary sewage. Considering that, the LWF system is seen as innovative in Latin American countries, and the importance of establishing an environmental plan to meet the Sustainable Development Goals (SDGs) is highlighted.

Another point to be highlighted in this dimension is the building documentation. As the LWF is little known, with specific workmanship and materials needed for repairs, it is important that the user manual provide details for both repair and maintenance. The manual should provide information necessary for the user to be able to purchase the established materials and perform proper repair and maintenance. Finally, in the evaluated building, the user manual, as well as the documents that refer to the system, were available to users.

\section{Dimension 4 application analysis result}

In dimension 4 all criteria were met. This dimension is comprised of the following structural durability, building maintenance and fence control criteria. The true analysis of these criteria will only be done after the occupation of the building, that is, when users are living and using the building in its entirety.

Without residents, these criteria have suffered little or no change. Therefore, it is recommended that this dimension should be checked frequently by the construction company and the residents annually.

\section{Dimension 5 application analysis result}

Dimension 5 presented a score of 24 out of 31 , that is, some criteria were not met, as Table 7 presents.

The sub-criteria "renewable energy management" is a requirement that this building does not have to accomplish. In its project, there were no actions for the management of natural resources, such as the use of rainwater, solar energy capture and protection against the release of pollutant gases by the materials used. SDG 7 discusses the need to improve global energy efficiency by promoting cleaner technologies and investment in energy infrastructure (NATION..., 2020).

The implantation, for example, of photovoltaic panels that make the solar capture is an action that can be incorporated in projects using the LWF system.

Table 7 - Dimension 5 Evaluation Theoretical score

\begin{tabular}{|c|c|c|c|c|}
\hline \multirow{2}{*}{ Dimension 5} & \multirow{2}{*}{$\begin{array}{c}\text { Theoretical } \\
\text { score }\end{array}$} & \multicolumn{2}{|c|}{ Practice } & \multirow{2}{*}{$\begin{array}{c}\text { Identified } \\
\text { score } \\
\end{array}$} \\
\hline & & Yes & No & \\
\hline \multicolumn{5}{|l|}{ 5.1 Satisfaction of residents } \\
\hline 5.1.1 Safety of life and real estate & 8 & $\mathrm{X}$ & & 8 \\
\hline 5.1.2 Feeling of "belonging to the environment" & 2 & $\mathrm{x}$ & & 2 \\
\hline 5.1.3 Feeling of well-being & 5 & $\mathrm{x}$ & & 5 \\
\hline 5.1.4 Productivity and Performance & 2 & $\mathrm{x}$ & & 2 \\
\hline \multicolumn{5}{|l|}{ 5.2 Energy efficiency } \\
\hline 5.2.1 Rainwater abstraction management & 1 & & & 0 \\
\hline 5.2.2 Renewable energy management & 1 & & $\mathrm{x}$ & 0 \\
\hline 5.2.3 Pollutant gas management & 1 & & $\mathrm{x}$ & 0 \\
\hline \multicolumn{5}{|l|}{5.3 Costs } \\
\hline 5.3.1 Maintenance costs (materials, equipment, people) & 2 & & $\mathrm{X}$ & 0 \\
\hline 5.3.2 Expected cost vs. actual (water, light, gas, etc.) & 2 & & $\mathrm{x}$ & 0 \\
\hline \multicolumn{5}{|l|}{ 5.4 Physical Appearance } \\
\hline 5.4.1 Quality of building materials & 4 & $\mathrm{x}$ & & 4 \\
\hline 5.4.2 Maintaining the physical appearance of the building & 3 & $\mathrm{x}$ & & 3 \\
\hline $\begin{array}{l}\text { Total } \\
\end{array}$ & 31 & $\mathbf{0}$ & $\mathbf{0}$ & 24 \\
\hline
\end{tabular}

208 Sotsek, N. C.; Leitner, D. S.; Maceno, M. M. C.; Marques, M. A. M.; Santos, A. de P. L. 
The integration of solar systems is a worldwide trend, and since the creation of photovoltaic panels in 1954, most innovative buildings has been using these systems (YU et al., 2019).

The adaptation of tiles, gutters and water boxes for rainwater collection is also an alternative to using this feature for cleaning outdoor areas. The study (LEONG et al., 2018) shows that domestic rainwater systems can provide over $90 \%$ of non-potable water for toilet flushing, laundry and irrigation among others.

In addition to these sub-criteria, the costs related to the maintenance of the infrastructure, the costs related to light, and water resources were not foreseen for this building. Gupta and Kapsali (2016) in their research, indicate the importance of having a forecast of building expenses in terms of maintenance and resources (light and water) to be able to make a comparison and thus, attest to the effectiveness of the project and diagnose possible failures during the constructive process.

According to the Brazilian Innovative Building Technologies Performance Evaluation Manual (FABRICIO; ONO, 2015), one of the most critical factors for innovative buildings, which may be the inhibiting factor for their expansion, is the issue of maintenance costs. In general, the specific materials for maintenance are higher, as most are inputs that are not produced in the country and, therefore, need to be imported.

The workforce needs to be qualified, so there are fewer professionals and consequently the cost increases.

For the user who also has minimal knowledge about the system, these factors negatively affect the interest in the building system. Therefore, this sub-criteria is important and has to be considered as a factor during the elaboration of these constructions.

\section{Conclusion}

In this case study, the identified building performance was $94 \%$, which demonstrates a high performance. But the most important here is not the numerical value identified, but the discoveries made with the application of the method, as they allow actions to be taken immediately and future situations to be prevented, thus avoiding larger future problems.

In this specific building, the following stand out: Fire Protection and Safety, Flexibility and Adaptability of the building system, Environmental Plan, Energy Efficiency and Costs. The project team for further evaluation should review these.

\section{Final considerations}

The result of this study provides guidance for those who want to evaluate the performance of light wood frame buildings, a system still considered innovative for Latin American countries.

The scoring structure was developed taking into consideration several parameters in order to approach the method in an objective and holistic way, seeking to highlight essential factors for the performance of a building.

It is believed that this study may contribute to the diffusion of the construction system in the country; that it will help managers involved in maintaining these buildings to achieve high user satisfaction, and that the methodological framework could serve as a basis for application in other countries employing the light wood frame system.

As suggestions for future work, it is recommended to apply the MEPLWF method throughout at least two phases of the life cycle of a project, pre-occupation and occupation, for example, to see how the result of a contribution to the development and evolution of the other.

In addition, the ideal is to develop the analysis mainly of dimension 2 in the winter and summer seasons, in order to measure the results according to the performance standard recommended.

\section{References}

ANTIKAINEN, R. et al. Renewal of forest based manufacturing towards a sustainable circular bioeconomy. Finnish Environment Institute, p. 1796-1726, 2017.

ASSOCIAÇÃO BRASILEIRA DE NORMAS TÉCNICAS. NBR 10151: acústica: avaliação do ruído em áreas habitadas, visando o conforto da comunidade: procedimento. Rio de Janeiro, 2000. Versão Corrigida 2003. 
ASSOCIAÇÃO BRASILEIRA DE NORMAS TÉCNICAS. NBR 10152: acústica: níveis de pressão sonora em ambientes internos a edificações. Rio de Janeiro, 2017.

ASSOCIAÇÃO BRASILEIRA DE NORMAS TÉCNICAS. NBR 15575-1: edificações Habitacionais: desempenho: parte 1: requisitos gerais. Rio de Janeiro, 2013a.

ASSOCIAÇÃO BRASILEIRA DE NORMAS TÉCNICAS. NBR 15575-4: edificações habitacionais: desempenho: parte 4: sistemas de vedações verticais internas e externas - SVVIE. Rio de Janeiro, 2013b.

BRASIL. Ministério das Cidades. SINAT No 005: Revisão 2. Sistemas construtivos estruturados em peças leves de madeira maciça serrada, com fechamentos em chapas (Sistemas leves tipo "Light Wood Framing"). Brasília, 2017.

FABRICIO, M. M.; ONO, R. Avaliação de desempenho de tecnologias construtivas inovadoras, avaliação de desempenho de tecnologias construtivas inovadoras. Porto Alegre: ANTAC, 2015.

GOLD, S.; RUBIK, F. Consumer attitudes towards timber as a construction material and towards timber frame houses - selected findings of a representative survey among the German population. Journal of Cleaner Production, v. 17, n. 2, p. 303-309, 2009.

GUPTA, R.; KAPSALI, M. Evaluating the 'as-built'performance of an eco-housing development in the UK. Building Services Engineering Research and Technology, v. 37, n. 2, p. 220-242, 2016.

HONG, Y. Environmental assessment criteria and protocols for residential developments. Master of Science (Bulding). Nationaal University of Singapore, Singapore, 2007.

IBEM, E. O. et al. Performance evaluation of residential buildings in public housing estates in Ogun State, Nigeria: Users' satisfaction perspective. Frontiers of Architectural Research, v. 2, n. 2, p. 178-190, 2013.

INTERNATIONAL ORGANIZATION FOR STANDARDIZATION. ISO 10052: acoustics: field measurements of airborne and impact sound insulation and of service equipment sound: survey method. Genève, 2004.

JADID M.; BADRAH M. Decision support system approach for construction materials selection. In: SYMPOSIUM ON SIMULATION FOR ARCHITECTURE AND URBAN DESIGN, Orlando, 2012. Proceedings [...] Orlando, 2012.

KARLSSON, I.; ROOTZÉN, R.; JOHNSSON, F. Reaching net-zero carbon emissions in construction supply chains: analysis of a Swedish road construction project. Renewable and Sustainable Energy Reviews, v. 120, 2020.

KHALIL, N.; KAMARUZZAMAN, S. N.; BAHARUM, M. R. Ranking the indicators of building performance and the users' risk via Analytical Hierarchy Process (AHP): case of Malaysia. Ecological indicators, v. 71, p. 567-576, 2016.

LAI, J. H. K.; MAN, C. S. Developing a performance evaluation scheme for engineering facilities in commercial buildings: state-of-the-art review. International Journal of Strategic Property Management, v. 21, n. 1, p. 41-57, 2017.

LEONG, J. Y. C. et al. Quantification of mains water savings from decentralised rainwater, greywater, and hybrid rainwater-greywater systems in tropical climatic conditions. Journal of Cleaner Production, v. 176, p. 946-958, 2018.

LIU, S.; QIAN, S. Evaluation of social life-cycle performance of buildings: theoretical framework and impact assessment approach. Journal of Cleaner Production, v. 213, p. 792-807, 2019.

MA, M. et al. A methodology to assess China's building energy savings at the national level: An IPATLMDI model approach. Journal of Cleaner Production, v. 143, p. 784-793, 2017.

MAHAPATRA, K.; GUSTAVSSON, L.; HEMSTROM, K. Multi-storey wood-frame buildings in Germany, Sweden and the UK. Construction Innovation, v. 12, n. 1, p. 62-85, 2012.

MOLINA, J. C.; CALIL JUNIOR, C. Sistema construtivo em wood frame para casas de madeira. Semina: Ciências Exatas e Tecnológicas, Londrina, v. 31, n. 2, p. 143-156, 2010.

NATION UNITED BRAZIL. Transformando nosso mundo: a Agenda 2030 para o desenvolvimento sustentável. Available: https://nacoesunidas.org/pos2015/agenda2030/'. Access: 19 apr. 2020.

210 Sotsek, N. C.; Leitner, D. S.; Maceno, M. M. C.; Marques, M. A. M.; Santos, A. de P. L. 
NAZEER, S. F.; SILVA, N. de. TBPE scoring framework for tropical buildings. Built Environment Project and Asset Management, v. 6, n. 2, p. 174-186, 2016.

SOTSEK, N. C. et al. Evaluation method for building performance in light wood frame in Brazil. Ambiente Construído, Porto Alegre, v. 20, n. 3, p. 553-572, jul./set. 2020.

SOTSEK, N. C.; SANTOS, A. L. de P. Panorama do sistema construtivo light wood frame no Brasil. Ambiente Construído, Porto Alegre, v. 18, n. 3, p. 309-326, jul./set. 2018.

TECVERDE. Panorama do sistema construtivo Tecverde. 2016. Available:

http://www.tecverde.com.br/wp-content/uploads/2016/02/Panorama-do-Sistema-Construtivo-Tecverde.pdf. Access: 25 apr. 2018.

WANG, L.; TOPPINEN, A.; JUSLIN, H. Use of wood in green building: a study of exert perspectives from the UK. Journal of Clean Production, v. 65, p. 350-361, 2014.

YU. Z. et al. Towards na optimized zero energy solar house: a critical analysis of passive and active design strategies used in Solar Decathlon Euroe in Madrid. Journal of Clenar Production, v. 236, 2019.

Nicolle Christine Sotsek

Programa de Pós-Graduação em Construção Civil, Centro Politécnico | Universidade Federal do Paraná | Av. Cel. Franscico H. dos Santos, 100, Prédio da Adminstração, $4^{\mathrm{a}}$ andar, sala 7, Jardim das Américas |Curitiba - PR - Brasil | CEP 81531-980 | Tel.: (41) 3361-3398 | Email: nicolleramos@ufpr.br

\title{
Drielle Sanchez Leitner
}

Programa de Pós-Graduação em Engenharia Civil, Centro Politécnico | Universidade Federal do Paraná | Av. Cel. Francisco H. dos Santos, 100, Jardim das Américas | Curitiba - PR - Brasil | CEP 81531-980 | Tel.: (41) 98443-2448 | E-mail: drielle.dsl@gmail.com

\section{Marcell Mariano Corrêa Maceno}

Programa de Pós Graduação em Engenharia de Produção, Centro Politécnico | Universidade Federal do Paraná | Av. Cel Franscico H. dos Santos, 100, Prédio da Adminstração, 4ª andar, sala 8, Jardim das Américas | Curitiba - PR - Brasil | CEP 81531-980 | Tel.: (41) 3361-3398 I E-mail: marcell.maceno@gmail.com

\section{Marcos Augusto Mendes Marques}

Programa de Pós Graduação em Engenharia de Produção, Centro Politécnico | Universidade Federal do Paraná | Av. Cel. Franscico H. dos Santos, 100, Prédio da Adminstração, 4a andar, sala 7, Jardim das Américas | Curitiba - PR - Brasil | CEP 81531-980 | Tel.: (41) 3361-3398 | E-mail: marquesammarcos@gmail.com

\section{Adriana de Paula Lacerda Santos}

Programa de Pós Graduação em Construção Civil, Centro Politécnico | Universidade Federal do Paraná | Av. Cel. Franscico H. dos Santos, 100, Prédio da Adminstração, 4a andar, sala 5, Jardim das Américas | Curitiba - PR - Brasil | CEP 81531-980 | Tel.: (41) 3361-3398 |

E-mail: adriana.pls1@gmail.com

\author{
Ambiente Construído \\ Revista da Associação Nacional de Tecnologia do Ambiente Construído \\ Av. Osvaldo Aranha, $99-3^{\circ}$ andar, Centro \\ Porto Alegre - RS - Brasil \\ CEP 90035-190 \\ Telefone: +55 (51) 3308-4084 \\ www.seer.ufrgs.br/ambienteconstruido \\ www.scielo.br/ac \\ E-mail: ambienteconstruido@ufrgs.br
}

